\title{
Can Top Down Participatory Budgeting Work? The Case of Polish Community Fund
}

\author{
Dawid Sześcito \\ Public Administration Research Unit, Faculty of Law and Administration, \\ University of Warsaw, Poland \\ dawid.szescilo@uw.edu.pl \\ Bartosz Wilk \\ Public Administration Research Unit, Faculty of Law and Administration, \\ University of Warsaw, Poland \\ b.wilk@wpia.uw.edu.pl
}

\section{ABSTRACT}

The article addresses the participatory budgeting (PB), which is one of the most recognised governance innovations of recent decades. This global phenomenon represents in practice a shift towards participatory and collaborative management of public resources at the local level. The purpose of this article is to determine when top down approach to PB might be welcomed, taking into account the characteristics of PB schemes all around the world that they emerged as local initiatives, instigated either by civil society groups or local governments. The analysis is based on the description of the PB example as introduced via country-wide legislation, exhaustively regulating PB procedure. The article examines Polish experience in the field of functioning top down approach to PB. It demonstrates that top down PB can effectively work, if it is accompanied with significant incentives and grants, as well as the extensive autonomy and flexibility of local communities. Polish experience suggests that such an initiative might be relatively successful, yet there is a number of conditions that has to be met in order to ensure the dissemination of legislative model of participatory budgeting. The results have practical implications to central government institutions that consider introduction of some legislative framework for participatory budgeting at the local level. The originality of the research is in the analysis of one of successful stories of the PB introduced via country-wide legislation, and determining when this approach can work, also in other countries

Keywords: community fund, participatory budgeting, participatory governance, local government, local budget, civil society, citizen participation, Poland

$J E L: K 23$ 


\section{Introduction}

Participatory budgeting (PB) is an umbrella term for wide array of governance experiments characterized by greater and more direct involvement of citizens in budgets formulation, setting spending priorities, expenditure monitoring and evaluation (Allegretti and Herzberg, 2004; Cabannes, 2004; Wampler, 2007). Numerous technical and institutional arrangements could be applied in PB processes, including public hearings, citizen surveys, advisory boards, forums, workshops, voting (budget referenda), citizen panels and focus groups (Zhang and Liao, 2011; Kim and Schachter, 2013).

Since Porto Alegre experiment in late 80s' PB became a global phenomenon in local governance and one of the most tangible signs of shift "from local government to local governance" and expansion of participatory governance, co-governance or collaborative governance (Bevir, 2012; Hordijk, 2012; Donaghy, 2013). It develops in polycentric manner (Dias 2014), yet we could distinguish some common denominator for most of its forms - PBs are local initiatives launched and elaborated by local governments, grass-roots activists and civil society groups. Only few countries (Peru, Bolivia, Dominican Republic) introduced top down PB, i.e. PB imposed by national legislation as mandatory arrangement for local governments (McNulty, 2004). Only Peruvian experience has been evaluated by Mc Nulty (2004) who provided rather mixed picture regarding the outcomes of this approach.

The article presents Polish experience connected with the introduction of topdown PB and the functioning of this mechanism, which is the community fund. This is to determine if the example of a community fund is a successful story, and if so, what data is the basis for the claim. In addition, the aim of the research is to determine the recommendation to be used in this approach to PB.

\section{Methods}

This article aims at general assessment of the top down PB introduced by national legislation in Poland, known as community fund for rural areas. Key element of this model is empowering the residents of rural areas (villages) to directly and conclusively decide on distribution of the part of communal budget, calculated according to national legislation and according to the procedure specified in this law.

The effectiveness of PB depends on various factors, which in the literature of the subject are divided into the governmental environment, the design of the process, the mechanisms used for elicit participation (Memeti and Kreci, 2016). In this article, the community fund's legal regulations will be analyzed in terms of factors that contribute to the development of PB, such as the governmental environment, the design of the process, the mechanisms used for elicit participation. 
The first step in the evaluation of the PB is to determine whether it is an instrument that is willingly used by citizens and public authorities, especially in case of top down PB. Introduction of community fund requires autonomous of each communal council, yet national legislation provides some financial incentives for that. Review of this arrangement is conducted with the use of statistical data regarding primarily the share of communal councils that introduced community fund and the total expenditure distributed according to this mechanism. Those quantitative indicators are complemented with literature review providing broader context of the reception of top down approach to PB in Poland.

\section{Results}

\subsection{Global expansion of participatory budgeting}

The idea of PB originated in Porto Alegre in late 80s', where advanced model of participation in budgetary process has been developed by the local government and over years became a global reference model (Ganuza and Baiocchi, 2014). Recommendations made by citizens in PB process are not formally binding, but there is strong pressure to include them, without modifications, into budgets adopted by appropriate local government bodies (Souza, 2001; Novy and Leubolt, 2005). Porto Alegre model offers direct and meaningful participation, yet PB covers also arrangements where local authorities save unrestricted and exclusive decision-making powers and citizens are only consulted (Sintomer, Herzberg and Röcke, 2008).

All models aim at enabling citizens to influence the allocation of public resources and educating them, enhancing transparency and accountability (Shah, 2007). However, the evaluation of efficiency and effectiveness of public resources allocation via PB is extremely difficult. One reason is lack of uniformed and homogenous model of PB. Another challenge is lack of agreement on the set of indicators for measuring success of PB. Outcomes and impacts of PB are reviewed most extensively in case of Porto Alegre, where PB is associated with improving access to public services for disadvantaged groups and reducing corruption in local government (World Bank, 2003; Baiocchi and Lerner, 2007; Cabannes, 2004; Sintomer Herzberg and Röcke, 2008).

PB is not by definition reserved only to local (municipal) budgets. However, both theoretical discourse and the practice of PB implementation focus on local government, including cities of all sizes, from small communes (below 20,000 inhabitants) to mega-cities (Cabannes, 2004). There are only few examples from higher level of government considered in the literature, including the state of Rio Grande do Sul, Brazil (Goldfrank and Schneider, 2006) or in the provinces of Chucampas, Celendín or Moropon Chulucanas, Peru (Cabannes, 2004).

Participatory budgeting is now global phenomenon, yet the scale of its diffusion is difficult to estimate. Sintomer et al. roughly calculated that there were 
between 1,269 and 2,778 participatory budgets in 2013 (Sintomer, Herzberg and Röcke, 2014). However, those estimations needs to be considered with special reservations, not only because of huge variety of models interpreted as PB. As PB emerges usually as local initiative, country-wide statistics are not always available.

\subsection{Participatory budgeting in Poland. Between bottom up and top down approach}

Participatory budgeting arrived to Poland only few years ago, yet it evolved rapidly into one of the most popular innovations in local governance. It has developed in two, parallel forms: 1) as bottom-up initiative promoted by civil society groups that managed to disseminate this concept among local authorities; and 2) as uniform, country-wide model established by national legislation. In 2018, from the new term of local self-government, come in force new legislation of PB in municipalities. PB will be mandatory in large local government units.

The former model is applied primarily in urban communes that are not allowed to apply the legislative arrangement („urban PB”). Urban PB until 2018 was not regulated in the national legislation at all and all procedures are established by local councils and mayors. National legislation does not require any public participation in planning public spending, both in a one-year perspective (annual budgets) and long-term planning (multi-year financial prognosis). Despite lack of uniform model, urban PB in vast majority of the Polish municipalities is implemented in very similar version, characterized by citizens' engagement restricted to a very minor part of local budget (less then $2 \%$ of planned expenditure), poor range of deliberation tools for engaging citizens in a dialogue on local budget, and procedure resembling local referendum (Sześcito, 2015). Urban PB is distributed via popular vote on the projects previously submitted by individual residents or civil society organizations. Vote is not formally binding to local council, yet it is usually reflected in the councils' decisions. This form of PB has been already implemented in over 80 municipalities (Kębłowski, 2014), while in 2011 there was only city (Sopot) experimenting with this method (Kębłowski, 2013). One of the Polish non-governmental organizations gathered in 2018 data on examples of 186 PB in Polish municipalities (Pracownia Badań i Innowacji Społecznych "Stocznia" 2018).

The provisions of the Act of 11 January 2018 on amending certain laws to increase the participation of citizens in the process of selecting, operating and controlling certain public bodies, introduced the concept of a PB at every level of self-government units. These provisions will come into force in the autumn of 2018, when the next, 5-year term of the local self-government authorities will start. The PB instrument has been included in the existing provisions regarding public consultations.

According to the new regulations, a PB is understood as a special form of public consultations, deciding on a part of budget expenditures in direct vot- 
ing. In the case of large local self-government units the obligation to separate the PB was introduced. PBs established in large cities in accordance with this obligation can not be less than $0.5 \%$ of the commune's expenditure included in the last report on the implementation of the budget.

The tasks of the council of the local government unit include defining, in the resolution, the requirements that the proposals for the PB should meet. This applies in particular: formal requirements that the submitted projects should respond to, the required number of signatures of residents supporting the project, rules for the assessment of submitted projects as to their compliance with the law, technical feasibility, formal requirements they meet and the procedure of appeal against the decision not to allow the proposal for voting, the rules governing the voting, determining the results and making them public.

Top down, legislative model of PB in the form of community fund has been adopted in February 2009 with the effect to local budgets for 2010. Law on the Community Fund ${ }^{1}$ has limited scope of application. Community funds might be introduced only in rural or urban-rural communes ${ }^{2}$ that created special auxiliary units for rural areas, called communities or villages (sotectwa). Communities does not enjoy any formal autonomy from communal authorities and do not have their own budgets and functions to be performed independently. They have no capacity to get into contractual relations. Decision on establishment of communities and specifying scope of their tasks is under exclusive competence of communal council. Typical functions delegated to communities includes organization of cultural or sports events, local roads improvement or flood protection. Traditionally, the elected representatives of communities supported communal administration in collecting local taxes (Kulesza and Sześcito, 2012). Currently, there are over 40,000 of communities in 2173 rural and urban-rural communes (Central Statistical Office of Poland, 2015).

Communities are managed according to the bylaws adopted by communal councils, yet the national legislation established community gathering of all residents as decision-making body for community and community mayor (sottys) as executive organ appointed by the gathering. Hence, communities might be perceived as a form of traditional direct democracy. It is feasible thanks to the size and population of communities that predominantly cover single village area.

Taking into account the formal status of community, community fund cannot be regarded as separate budget of this unit (Paczocha, 2009; Augustyniak, 2010). Extracting community fund from the communal budget is not mandatory. However, if the communal council once decided on establishing the fund for a given year, this decision remains valid also for subsequent years, until it

1 Law of 20 February 2009 on the Community Fund, Journal of Laws, No. 52, pos. 420. This law has been replaced by the Law of the Community Fund, Journal of Laws, pos. 301 that entered into force on 20 March 2014.

2 Rural communes covers only rural areas (villages), while urban-rural communes consists of town and surrounding rural areas (villages). 
is repealed by special resolution of the council. On the other hand, the resolution on the non-separation of the community fund may cover only one year. This means that in the next year local authorities will have to reconsider the creation of the community fund. This contributes to greater stability of this arrangement and minimizes the risk of its abandoning.

If the community was created, it must be implemented in accordance with the standards and procedures specified in the Law on the Community Fund. First of all, the minimal amount of the fund needs to be calculated according to statutory formula. This amount might be increased by the communal council. This formula takes into account two variables relating to population and income capacity of the commune: 1) number of residents of each community; and 2) communal budget income per capita.

Although community fund is covered entirely from communal budget, the Law on the Community Fund contains partial refund scheme addressed to the communes. They are entitled to receive from the state budget reimbursement of up to $40 \%$ of their expenditure on the community fund. The highest refund might be granted to the communes with the budget income per capita below the national average. This mechanism plays crucial role in incentivizing communes to introduction of the community fund.

The decision-making process on distribution of already calculated amount of community fund is set out in the Law on the Community Fund. It includes four main stages described below.

Figure 1. Management of the community fund

\section{APPLICATION}

- Community gathering, open to all residents of the community, adopts the list of the projects to be implemented within the community fund. The projects need to be compatible with the scope of communal tasks and contribute to improving the quality of life of residents

- The application should describe each project, explain their rationale and estimate their costs. Estimation of total costs of all projects cannot exceed the amount established by the communal council as community fund for a given community

- Full list of projects adopted by the community gathering is submitted to the mayor of the commune 


\section{REVIEW}

- $\quad$ The mayor may reject the application solely on formal grounds, e.g. incomplete or adopted with procedural errors

- In case of rejection, the community mayor may uphold the resolution of the gathering and submit it directly to the communal council

- Alternatively, the community gathering may rectify its resolution and resubmit it to the mayor

\section{DECISION}

- The mayor includes the projects submitted by the communities into communal budget proposal

- Communal council, while considering budgetary proposal, has to accept the communities' application

- The application might be rejected by the communal council only in case of incompatibility with the local development strategy, does not fit into catalogue of communal tasks or does not contribute to improving the quality of life of the residents

\section{IMPLEMENTATION}

- The projects are implemented as typical communal initiatives (investments), i.e. by the communal administrative apparatus. No funds are transferred directly to the community and community representatives does not have direct competences in the process of projects' implementation

- There are no legislative guarantees of community's participation in projects' implementation or evaluation

- However, during the budgetary year the community gathering may apply for modifications and alterations of the list of projects or detailed content of each project

Source: based on 2014 Law on the Community Fund.

In practice, the community funds are allocated primarily to the investments in local transport and communication infrastructure (36\% of total allocation in 2014), culture, e.g. running community cultural centers $(25,7 \%$ in 2014$)$ and maintenance of public utilities (13,9\% in 2014), including parks, streets, squares and green areas (Council of Ministries of the Republic of Poland, 2015). For comparison, in 2017 expenditures made under the community fund were mainly related to transport and communication $(32.6 \%$, and especially to municipal roads), culture and protection of national heritage (24.6\% and especially for houses and cultural centers), municipal economy and environmental protection (17.2\%, and in this mainly for lighting of streets, squares and roads, and maintenance of greenery), or finally physical culture (9.6\%, and mainly on sports facilities; Council of Ministries of the Republic of Poland, 2018). 


\section{Discussion}

Introducing PB as top down initiative, driven by national legislation was a risky endeavor, taking into account the dominant approach to PB as locally, bottom up instigated governance innovation. The main question is, therefore, if the local communities approved and absorbed this uniform and regulated in detail scheme. Considering the key elements of the model set by the Law on the Community Fund, the following indicators might be used in order to assess the reception of the community fund at the local level:

- The number (share) of communes that adopted the community fund;

- The total expenditure on the community fund that was realized (not only planned).

Data for this research has been provided by the Ministry of Public Administration, Council of Ministers of the Republic of Poland, Central Statistical Office of Poland, National Community Mayors' Association and Watchdog Polska (non-governmental organization monitoring the implementation of community funds across the country).

The number (share) of communes that - via resolutions of communal councils - decided to introduce community fund is the main indicator of the reception of this mechanism among local communities. As the decision in this matter is absolutely voluntary, this indicator explicitly reflects the level of acceptance and legitimacy of top down PB in the form of community fund. The figure below illustrates the dissemination of community fund among rural and urban rural communes since the introduction of this mechanism in the local budgets for 2010.

Figure 2. The number of communes that introduced the community fund (total number of rural and urban-rural communes: 2173 )

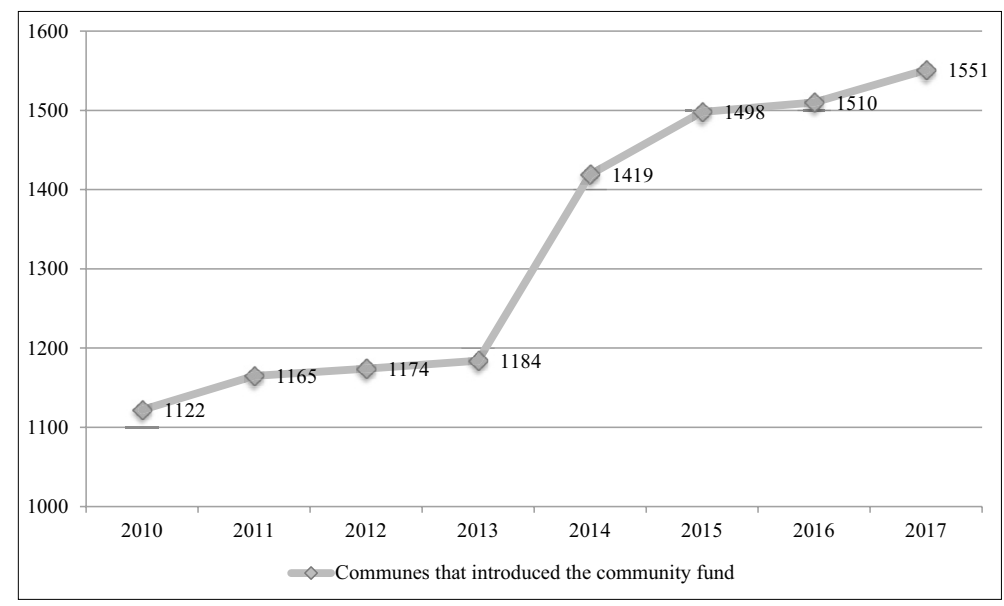

Source: Ministry of the Interior and Administration 2018, <http://administracja.mswia. gov.pl/adm/Fundusz-solecki/statystyka/10370,Fundusz-solecki-w-liczbach.html>. 
Broad dissemination the community fund over the years is evident. In 2015 it functioned in $64 \%$ of the communes, and in 2017 - 71,31\%. Rapid expansion of this instrument occurred in 2014 when the new Law on the Community Fund entered into force, providing some technical arrangements facilitating implementation and management of the funds ${ }^{3}$. Six years' experience is long enough to conclude that the community fund gained stable and noticeable position in the local landscape of Poland. In terms of number (share) of communes that implemented $\mathrm{PB}$, community fund appeared to be much more popular than urban PB adopted according to rules and procedures set out entirely by local government. Community fund was not rejected as a formula contradictory to the idea of local governments' autonomy and inconsistent with the global trends in PB's development. Top down, essentially bureaucratic approach has been approved the majority of the local government and the level of acceptance remained high over the years.

Figure 3. Share of communes in which the community fund was established, to the number of all communes in which there are auxiliary units for rural areas (sotectwa)

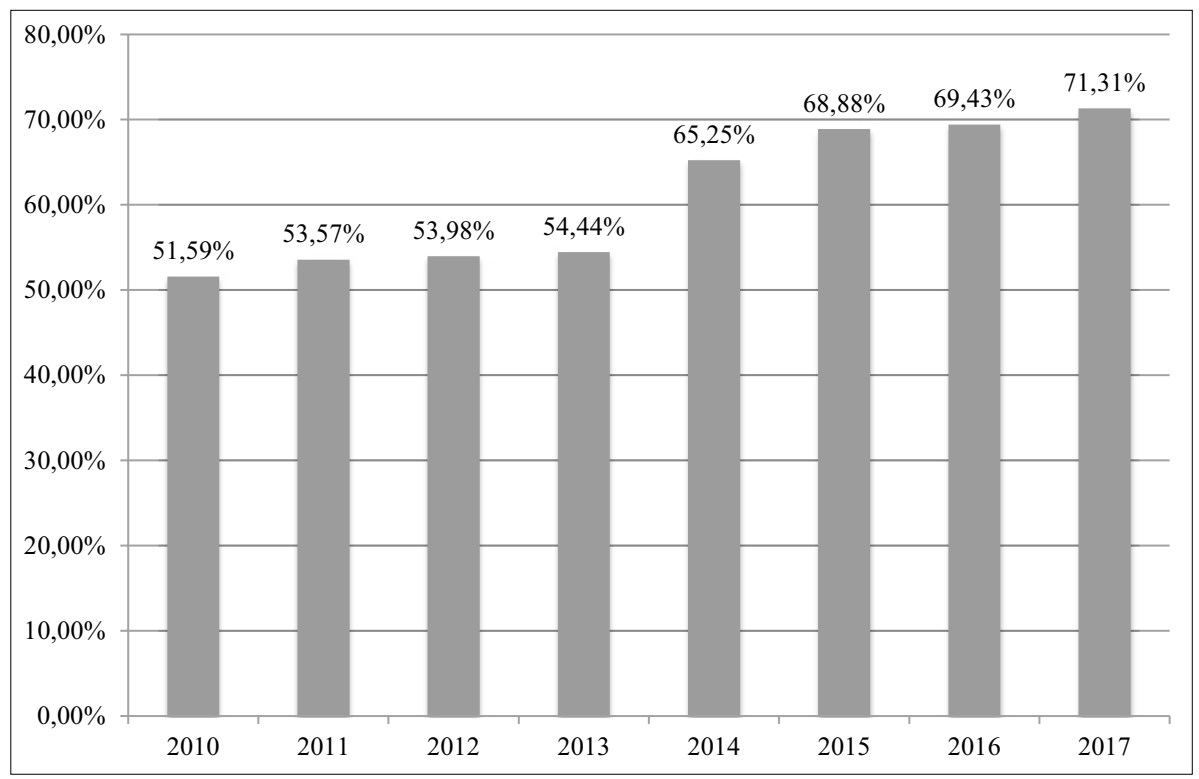

Source: Reply of the deputy Minister of the Interior and Administration to interpellation No. 24306 on the scope of dissemination of the community fund.

What is more, the total share of community fund in the budgets of rural and urban-rural communes increases faster than the number of communes using this mechanism (figure 3). While the number of communes applying community fund increased by $4 \%$ between 2010 and 2014, the share of budgets allocated to the community fund grew by $53 \%$ in case of rural communes and

3 For instance, the available refund from central budget was increased and joint applications from more communities were allowed. 
by $52 \%$ in case of urban-rural communes. This means that increasing number of communes decided to set allocations for community funds above statutory minimum. However, there are no comprehensive statistics on the share of communes, where the extra allocation has been provided.

Figure 4. Share of budgets of rural and urban-rural communes allocated to the community fund

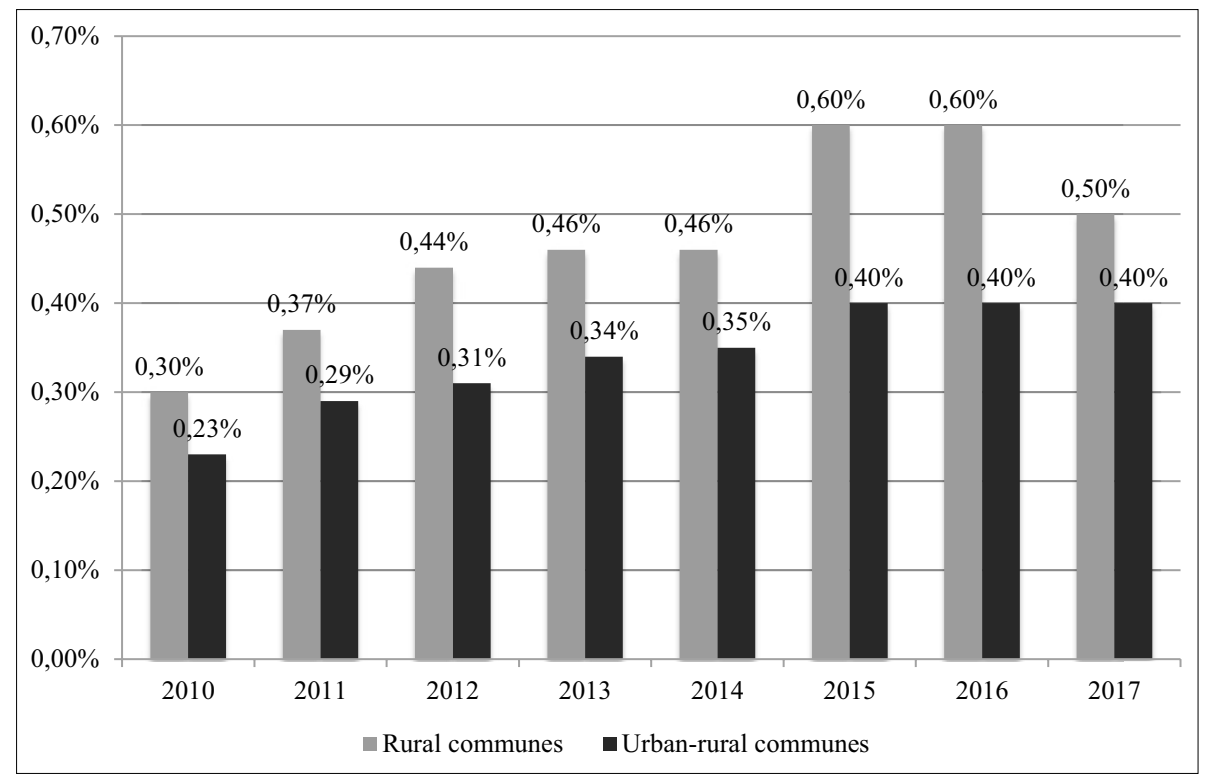

Source: Council of Ministers of the Republic of Poland, 2015, 2016, 2017, 2018, Central Statistical Office of Poland, 2014.

This effect cannot be linked only with the financial incentive for community fund's implementation. Firstly, the refund scheme activates ex post. This means for the municipality that the refund will take place in the next budget year in relation to the year in which the expenditure was made.. Furthermore, the amount of available refund is strictly limited, as mentioned above. What are the other factors that contributed to high reception of the community fund among local governments? First of all, it is crucial to take into account the historical context. Law on the Community Fund did not introduce completely new instrument, yet institutionalize and developed the mechanism that has been already applied in some communes. It needs to be reminded, the Communal Government Act contained (and still contains) provisions enabling local governments to empower communities to manage specified share in communal budget (Trykozko, 2014). Detailed procedures for setting this share and disposing it should be established in the commune's bylaws. Traditionally, one of the most popular instruments adopted locally were so called "community deductions" - mechanism very similar to the community fund, i.e. based on authorizing the community to dispose the share of local budget cal- 
culated primarily with reference to community population. Sobiesiak-Penszko (2012) claim that the community fund has been introduced most extensively in the regions where the practice of community deductions or other similar instruments was most disseminated.

It is clear, therefore, why the Law on the Community Fund has been contested by the Polish Association of Rural Governments as limiting the communal autonomy (Swianiewcz, 2011). The introduction of uniform legislative model interfered with well established and developed locally practices. On the other hand, this law secures wide scope of autonomy for communal councils in determining key elements of community funds on their territory. What is essential, the communal councils are allowed not to introduce community fund in the formula imposed by the legislation and may continue to use their own scheme. Obviously, financial incentives made the legislative model of community fund more attractive, yet regulatory approach reflected in the Law on the Community Fund is relatively flexible and general. It focuses on setting minimum standards and protecting communities against arbitrary decisions of the communal councils or mayors. Communal councils are still authorized to make final decision on the allocation of funds to the communities and under circumstances that are broadly defined (see: figure 1) it may reject the community's proposal. The mayor has supervisory powers over the activities of community bodies and is entirely responsible for implementation of the projects selected by the communities.

Hence the communal autonomy is not undermined by the Law on the Community Fund. The major drawback of this law is rather lack of sufficient guarantees for empowerment of communities, primarily in the phase of projects implementation. The role of the communities ends up when the list of projects is submitted to the communal authorities. They are not provided with any rights to participate in the final decision-making and or realization of the projects. The same disadvantages have also introduced in 2018 PB and mentioned above regulation of PB, based on the mechanism of public consultations. As they do not enjoy judicial capacity, they cannot challenge in the administrative courts any decisions and actions undertaken by the commune with regard to the community fund. They need to rely on, in this matter, central government's bodies performing supervision over local governments. Therefore, introduction of the community fund might be perceived as an important, yet cautious step towards communities' empowerment.

As previously mentioned, in 2018, from the new term of local self-government, come in force in Poland new legislation of PB in municipalities. PB will be mandatory in large local government units. These regulations are questionable, because the legislator did not react to raised doubts about the organization of the former PB in the construction of public consultations (consultations do not constitute a decision). In addition, the adopted regulations do not correspond to new trends, in which votes are changed to discuss the best solutions in small groups (this is also characteristic for community fund). 
Next years will show the functioning of this type of top down PB, presented different approach than in the case of community fund.

\section{Conclusion}

The case of Polish community fund proves that participatory budgeting might be effectively introduced via national legislation, yet specific conditions needs to be met in order to ensure acceptance of this approach among local communities. Firstly, the final decision on applying the legislative model of PB should be reserved to the competence of local governments. Autonomy of local governments needs to be combined with stimulants and incentives encouraging communities to follow the model set out in the legislation, primarily incentives of financial nature. What is also crucial, is to limit the legislative framework to setting minimum standards for the PB's procedure and leaving enough room for local governments to control detailed elements of the process. Finally, the historical context also matters. Success of the community fund was enhanced by the past experience with similar arrangements initiated and applied at local level. Law on the Community Fund institutionalized and disseminated those practices.

Important reservations need to be made to the general claim of the success of the community fund. Although the community fund became significant element of local governance and got absorbed „internalized" by the communities, more in-depth analysis is required in order to assess its impact on the quality of life and public services in rural areas or efficiency of the allocation of public resources via this mechanism. 


\section{References}

Augustyniak, M. (2010). Jednostki pomocnicze gminy. Warsaw.

Allegretti, G. and Herzberg, C. (2004). Participatory budgets in Europe. Between efficiency and growing local democracy. TNI Briefing Series 5.

Baiocchi, G. and Lerner, J. (2007). Could Participatory Budgeting Work in the United States? The Good Society, 16, pp. 8-13.

Bevir, M. (2012). Governance: A Very Short Introduction. Oxford.

Cabannes, Y. (2004). Participatory budgeting: a significant contribution to participatory democracy. Environment and Urbanization, 16(1), pp. 27-46.

Council of Ministers of the Republic of Poland. (2015). Sprawozdanie z wykonania budżetu państwa za okres od 1 stycznia do 31 grudnia 2014 r. Informacja o wykonaniu budżetów jednostek samorządu terytorialnego, Warsaw.

Council of Ministers of the Republic of Poland. (2016). Sprawozdanie z wykonania budżetu państwa za okres od 1 stycznia do 31 grudnia 2015 r. Informacja o wykonaniu budżetów jednostek samorządu terytorialnego. Warsaw.

Council of Ministers of the Republic of Poland. (2017). Sprawozdanie z wykonania budżetu państwa za okres od 1 stycznia do 31 grudnia 2016 r. Informacja o wykonaniu budżetów jednostek samorządu terytorialnego, Warsaw.

Council of Ministers of the Republic of Poland. (2018), Sprawozdanie z wykonania budżetu państwa za okres od 1 stycznia do 31 grudnia 2017 r. Informacja o wykonaniu budżetów jednostek samorządu terytorialnego. Warsaw.

Dias, N. (Ed.) (2014). 25 Years of participatory budgeting worldwide. São Brás de Alportel : In Loco Association.

Donaghy, M. (2013). Civil Society and Participatory Governance. Routledge Press.

Gauza E. and Baiocchi, G. (2014). Participatory Budgeting as if Emancipation Mattered. Politics and Society, 42 (1), pp. 29-50.

Goldfrank, B. and Schneider A. (2006). Competitive Institution Building: The PT and Participatory Budgeting in Rio Grande do Sul. Latin American Politics and Society, 48(3), pp. 1-31.

Hordijk, M.A. (2012). Citizenship, local governance and democracy. In N. Pouw, I. S. A. Baud and T. Dietz, Local Governance and Poverty in Developing Nations. London: Routledge, p. 203.

Kębłowski, W. (2013). Budżet partycypacyjny. Krótka instrukcja obsługi. Warsaw: Instytut Obywatelski.

Kębłowski, W. (2014). Budżet partycypacyjny. Ewaluacja. Warsaw.

Kim S. and Schachter, H.L. (2013). Citizen Participation in the Budget Process and Local Government Accountability, Public Performance and Management Review, 36(3), pp. 456-471.

Kulesza, M. and Sześcito D. (2012). Local Government in Poland. In A. M. Moreno, ed., Local Government in the Member States of the European Union: A Comparative Legal Perspective. Madrid: INAP, pp. 485-504.

McNulty S. (2004). An unlikely success: Peru's top-down participatory budgeting experience. Journal of Public Deliberation, 8(2), pp. 1-19.

Memeti, M. and Kreci, V. (2016). Role of Municipal Council in Increasing Citizen Participation at the Local Budget Process. International Public Administration Review, 14(2-3), pp. 53-73. 
Ministry of the Interior and Administration. (2018). At <http://administracja.msw ia.gov.pl/adm/fundusz-solecki/statystyka/10370,Fundusz-solecki-w-liczbach. html>, accessed 1 September 2018.

Novy, A. and Leubolt, B. (2005). Participatory Budgeting in Porto Alegre: Social Innovation and the Dialectical Relationship of State and Civil Society. Urban Studies, 42(11), pp. 2023-2036.

Paczocha M. (2009). Fundusz sołecki jako narzędzie realizacji zadań gminy przez sołectwa. Finanse Komunalne. 7-8, p. 5.

Pracownia Badań i Innowacji Społecznych „Stocznia”. (2018). At < https://bp.party cypacjaobywatelska.pl/porownywarka-budzetow>, accessed 1 September 2018.

Reply of the deputy Minister of the Interior and Administration to interpellation No. 24306 on the scope of dissemination of the community fund.

Sintomer, Y., Herzberg, C. and Röcke A. (2014). Participatory Budgeting in Europe: Democracy and public governance. London.

Sintomer Y., Herzberg C. and Röcke, A. (2008). Participatory Budgeting in Europe: Potentials and Challenges. International Journal of Urban and Regional Research, 32(1), pp. 164-178.

Shah, A. (2007). Participatory Budgeting. Washington: World Bank.

Sobiesiak-Penszko, P. (2012). Partycypacja publiczna w sotectwach, czyli o mechanizmie funduszysołeckich - studia przypadku. In P. Sobiesiak-Penszko, ed., Prawo a partycypacja publiczna, Warsaw: Instytut Spraw Publicznych, pp. 109-122.

Souza, C. (2001). Participatory Budgeting in Brazilian cities: Limits and Possibilities in Building Democratic Institutions Environment and Urbanization, 13(1), p. 177.

Sześciło, D. (2015). Samoobsługowe państwo dobrobytu. Czy obywatelska koprodukcja uratuje ustugi publiczne? Warsaw.

Swianiewicz, P. (2011). Poland: Europeanization of Subnational Governments. In J. Louglin, F. Hendriks and A. Lidström, ed., The Oxford Handbook of Local and Regional Democracy in Europe. Oxford: Oxford University Press, pp. 480-504.

Trykozko R. (2014). Model uprawnień jednostki pomocniczej w procesach planowania i wykonywania budżetu gminy, Warsaw.

Zhang, Y. and Yuguo L. (2011). Participatory budgeting in local government: Evidence from New Jersey Municipalities. Public Performance and Management Review, 35(2), pp. 281-302.

Wampler, B. (2007). A Guide to Participatory Budgeting. In A. Shaw, ed., Participatory Budgeting. Washington: World Bank, pp. 21-54.

World Bank. (2003). Making Services work for Poor People: World Development Report 2004. Washington: The World Bank. 